\title{
Retinoic Acid Modulates Gap Junctional Permeability: A Comparative Study of Dye Spreading and lonic Coupling in Cultured Cells
}

\author{
Franz Brümmer, Günther Zempel, Peter Bühle, Johannes-Christoph Stein, and Dieter F. Hülser ${ }^{1}$ \\ Abteilung Biophysik, Biologisches Institut, Universität Stuttgart, Pfaffenwaldring 57, 7000 Stuttgart 80, FRG
}

\begin{abstract}
All-trans retinoic acid (RA), which was recently identified as a morphogen, affects gap junctional permeability in a dose- and time-dependent manner. In five different established mammalian cell lines (FL, BRL, BICR/M1R, HEL37, BT5C1) $100 \mu \mathrm{mol} / \mathrm{liter}$ RA reduced Lucifer yellow spreading within $30 \mathrm{~min}$ to 20 $50 \%$ of the control. Ionic coupling, however, remained almost unaffected under the same conditions. Freezefractured membranes of untreated and RA-treated cells were similar with regard to frequency and sizes of gap junction plaques. With concentrations of less than 10 $\mu \mathrm{mol} / \mathrm{liter} \mathrm{RA}$ the dye spreading increased significantly in the human amniotic cell line FL, pointing to a possible modulatory effect of RA on junctional communication. (1991 Academic Press, Inc.
\end{abstract}

\section{INTRODUCTION}

Intercellular communication can be mediated by membrane proteins which form junctional complexes between cells: the gap junctions. They are widely distributed in animal tissues [1] and regulate the intercellular exchange of small molecules up to $M_{\mathrm{r}}=900$ [2]. Gap junctions in excitable tissues-including heart [3], smooth muscles [4], and neurons [5] - provide a path for electrical signaling which is essential for coordinated functions. In nonexcitable tissues, e.g., liver or embryonic cells, gap junctions allow the exchange of metabolites and of molecules with regulatory functions $[1,6-8]$.

Retinoids, the natural or synthetic derivatives of vita$\min \mathrm{A}$, were described to influence the gap junctional permeability, both inhibiting [9-14] and stimulating [13] the dye spreading in different cell cultures. Since Wolbach and Howe [15] described the cellular effects of vitamin A deficiency in rat, various effects on biological systems caused by retinoids were detected $[16,17]$. Recently, all-trans retinoic acid (RA) was identified as a morphogenic substance in the developing chick limb bud [18] and in cultured cells [19].

\footnotetext{
${ }^{1}$ To whom correspondence and reprint requests should be addressed.
}

In our comparative study we demonstrate with several cell lines time-dependent effects of RA on gap junctional permeability with doses which may cause a differentiation. As measured with Lucifer yellow $\mathrm{CH}$, large molecules were retained with a much higher efficacy than ionic current when the cells were treated with 100 $\mu \mathrm{mol} /$ liter RA. Under these medium-conditions, the input resistance was considerably increased. Investigations with the electron microscope, however, showed no RA induced alterations of gap junction plaques. At concentrations $\leqslant 10 \mu \mathrm{mol} /$ liter RA both current and dye coupling was increased in FL cells. Preliminary reports of our results have been published as abstracts $[20,21]$.

\section{MATERIALS AND METHODS}

Cell culture. Only established cell lines were used for this investigation: BICR/M1R , fibroblastoid cells derived from a rat mammary tumor [22]; BT5C1, rat glioma cells [23]; BRL, epitheloid rat liver cells [24]; FL, epithelial cells derived from human amniotic membrane [25]; HEL37, mouse epidermal cells [26].

All cell lines were cultivated in Dulbecco's modified Eagle's medium (Biochrom KG, Berlin, FRG) supplemented with $3.7 \mathrm{~g} / \mathrm{liter}$ $\mathrm{NaHCO}_{3}, 100 \mathrm{mg} /$ liter streptomycin sulfate, $150 \mathrm{mg} / \mathrm{liter}$ penicillin $\mathrm{G}$, and $10 \%$ calf serum at $\mathrm{pH} 7.4$ and $37^{\circ} \mathrm{C}$ in a humidified incubator with $8 \% \mathrm{CO}_{2}$ /air mixture. Cells were passaged in tissue culture flasks (Nunc, Roskilde, Denmark) by treatment with $0.25 \%$ trypsin in phosphate-buffered solution (PBS) without calcium and magnesium. For the experiments cells were cultured in plastic petri dishes (Falcon $3002 \mathrm{~F}$, Becton-Dickinson, Mountainview, USA) and used as confluent monolayers or at low density (cell pair measurements). Retinoic acid (RA, Type XX, all-trans; Sigma, St. Louis, MO) was added at different concentrations in dimethyl sulfoxide (DMSO; Serva, Heidelberg, FRG). The concentration of DMSO in the medium did not exceed $1 \%$. Additional control experiments without RA were performed with solutions containing $1 \%$ DMSO.

Intercellular communication measured by dye transfer. Glass micropipettes were pulled from capillary glass (Hilgenberg Glas, Malsfeld, FRG) with a vertical pipette puller (700 C, David Kopf Instruments, Tujunga, USA), and backfilled with $4 \%(\mathrm{w} / \mathrm{v})$ solution of Lucifer yellow $\mathrm{CH}$ (Sigma) in $1 \mathrm{~mol} / \mathrm{liter} \mathrm{LiCl}$. The dye was iontophoretically injected into individual cells for 5-10 s with a negative current of about $20 \mathrm{nA}$ supplied by the iontophoresis unit of a microelectrode amplifier (L/M-1, modification $500 \mathrm{M} \Omega$, List-electronic, Darmstadt, FRG). All electrophysiological measurements were performed under phase contrast microscopes and the microelectrodes were operated by micromanipulators with electrical drives (DC3 + STM3, Gebr. Märzhäuser, Wetzlar, FRG).

The incidence of permeable junctions was scored under epifluorescence illumination (Filter sets 05 or 09 , Zeiss, Oberkochen, FRG) in 
first-order neighbors of the injected cell 2 min after stopping the iontophoresis of the dye [27]. A normalized coupling ratio is given by $\mathrm{CR}_{\mathrm{f}}$ $=\left(\mathrm{N}_{\mathrm{f}} / \mathrm{N} 1\right) \times 100$ where $\mathrm{N1}_{\mathrm{f}}$ is the number of dye coupled and $\mathrm{N} 1$ the total number of first order neighbors. Photographs were taken on Ilford HP5 films.

Intercellular communication measured by ionic coupling. In addition to the microelectrode (E1) filled with Lucifer yellow $\mathrm{CH}$ a second electrode (E2) backfilled with $3 \mathrm{~mol} /$ liter $\mathrm{KCl}$ was used which was connected to another $\mathrm{L} / \mathrm{M} 1$ microelectrode amplifier. Both microelectrodes were inserted into adjacent cells, the dye was injected with $E 1$ as described above and, in addition, square pulses of $3 \mathrm{nA}$ were applied. The resulting pulses were traced with $\mathrm{E} 2$ in adjacent cells together with their membrane potentials. Corresponding to the coupling ratio measured with Lucifer yellow $\left(\mathrm{CR}_{\mathbf{f}}\right)$ the extent of ionic coupling can be quantified in the same way by counting both the number $\mathrm{N}_{\mathrm{el}}$ of ionically coupled and the total number $\mathrm{N} 1$ of first order neighbors: $\mathrm{CR}_{\mathrm{el}}=\left(\mathrm{N1}_{\mathrm{el}} / \mathrm{N} 1\right) \times 100$. Ionic coupling between cell pairs was determined with two intracellularly inserted electrodes as described by Dertinger and Hülser [28] and their coupling ratio $\mathrm{V}_{2} / \mathrm{V}_{1}$ is given according to Loewenstein and Kanno [29].

Values are presented as means \pm standard error. Significance was tested using the Mann-Whitney $U$ test $[30,31]$ and the confidence level ( $P$ value) refers to the corresponding controls.

Electron microscopy. Monolayers were washed twice in PBS, fixed with $2.5 \%$ glutaraldehyde in PBS for $30 \mathrm{~min}$ at room temperature, and glycerinated for cryoprotection. Before freeze fracturing in a Balzers BAF 301 instrument at $-150^{\circ} \mathrm{C}$, the cells were frozen rapidly by propane dip. Fractured cells were replicated by platinum-carbonand carbon-evaporation. Replicas were cleaned for up to $18 \mathrm{~h}$ in sodium hypochlorite and washed $5 \times$ in distilled water. Electron micrographs were taken with a Zeiss EM 10 electron microscope.

\section{RESULTS}

\section{Dye Coupling}

When microinjected into a coupling competent cell, the fluorescent dye Lucifer yellow $\mathrm{CH}$ spreads intercellularly into contiguous cells as is demonstrated for BRL cells in Fig. 1. Addition of $100 \mu \mathrm{mol} / \mathrm{liter}$ RA reduces the number of dye-coupled cells within $30 \mathrm{~min}$ considerably and to a higher degree after $24 \mathrm{~h}$. The original dye coupling is resumed within 30 min after washing RA off the cells. The quantitative data of this uncoupling effect are given in Table 1 for five different cell lines.

\section{Ionic Coupling}

Although the dye transfer in all five cell lines was significantly reduced $(P<0.01)$ after addition of 100 $\mu \mathrm{mol} /$ liter RA, the spreading of ionic current was less affected in the three cell lines where the electrical coupling was tested. Table 1 summarizes these results which were obtained $30 \mathrm{~min}$ after adding $100 \mu \mathrm{mol} / \mathrm{liter}$ $\mathrm{RA}$ to FL, BRL, and BICR/M1R $\mathrm{R}_{\mathrm{k}}$ monolayer cultures. Even after $24 \mathrm{~h}$ incubation with the same amount of RA the electrical coupling was not reduced as drastically as the dye coupling. As can be seen from Table 1 the dye spreading in FL cells decreased with incubation time. We, therefore, investigated the time course of the effect of RA on junctional communication with FL cells grown as monolayers. After different incubation periods both dye and current spreading were measured. Dye spreading reached its minimum of $\mathrm{CR}_{\mathrm{a}} \sim 10 \%$ after a 2 -h treatment and remained at this level. Current spreading was only slightly affected by this concentration of RA. It decreased to constant values $\mathrm{CR}_{\mathrm{el}}$ of about $90 \%$ with a minimum of about $70 \%$ after $1 \mathrm{~h}$ (Fig. 2).

The intercellular communication in FL and BRL cells was also measured at isolated cell pairs where any effect will be detected with a higher sensitivity than in monolayer culture. The ionic coupling between pairs of FL and BRL cells, respectively, was reduced only slightly after addition of $100 \mu \mathrm{mol} / \mathrm{liter} \mathrm{RA}$ as can be seen from Table 2.

\section{Reestablishing Dye Transfer}

The recovery from RA-mediated inhibition was very fast: dye spreading, as in the controls, resumed within 30 min after removal of RA when the cells had been incubated with $100 \mu \mathrm{mol} /$ liter RA for $30 \mathrm{~min}$. In BRL cells, even after $24 \mathrm{~h}$ incubation, the dye transfer regained $66 \%$ of its control values within 30 min after washing (Table 1 , see also Figs. $1 \mathrm{~g}$ and $1 \mathrm{~h}$ ). One hour after removal of RA the dye transfer in FL cells was almost $20 \%$ higher than the control value (Table 1 ). Therefore, the effect of lower concentrations of RA on dye transfer was tested with FL cells. The data obtained after treating FL monolayer cells for $1 \mathrm{~h}$ with $10 \mu \mathrm{mol} /$ liter to $0.01 \mu \mathrm{mol} /$ liter RA are shown in Fig. 3. Under these low concentrations significantly higher dye spreading ( $P \leqslant 0.01$ for $10 \mu \mathrm{mol} /$ liter to $0.01 \mu \mathrm{mol} /$ liter RA) and slightly increased ionic coupling ( $P \leqslant 0.10$ for 1 and $0.1 \mu \mathrm{mol} /$ liter RA; $P \leqslant 0.20$ for $0.01 \mu \mathrm{mol} /$ liter RA) were observed.

\section{Electron Microscopic Observations}

The intercellular passage of dye molecules is enabled by gap junctions which have been found electron microscopically in all five cell lines. BICR/M1R cells ẁere characterized by large, FL cells by small and the other three cell lines by intermediate sizes of gap junction plaques. When the cells were treated with $100 \mu \mathrm{mol} /$ liter RA for 30 min no qualitative differences in plaque sizes and distribution of the particles were seen; we, therefore, did not perform a quantitative analysis of gap junction plaques.

\section{DISCUSSION}

An induced inhibition of gap junctional communication by RA as determined with Lucifer yellow was first reported for epithelial rat liver cells (BRL) where the dye spreading disappeared within $2 \mathrm{~min}$ after $100 \mu \mathrm{mol} /$ liter RA was added $[8,9]$. Similar results were found with mouse embryo limb mesenchymal cells which reacted upon $3.3 \mu \mathrm{mol} / \mathrm{liter} \mathrm{RA}$ by a loss of dye coupling 

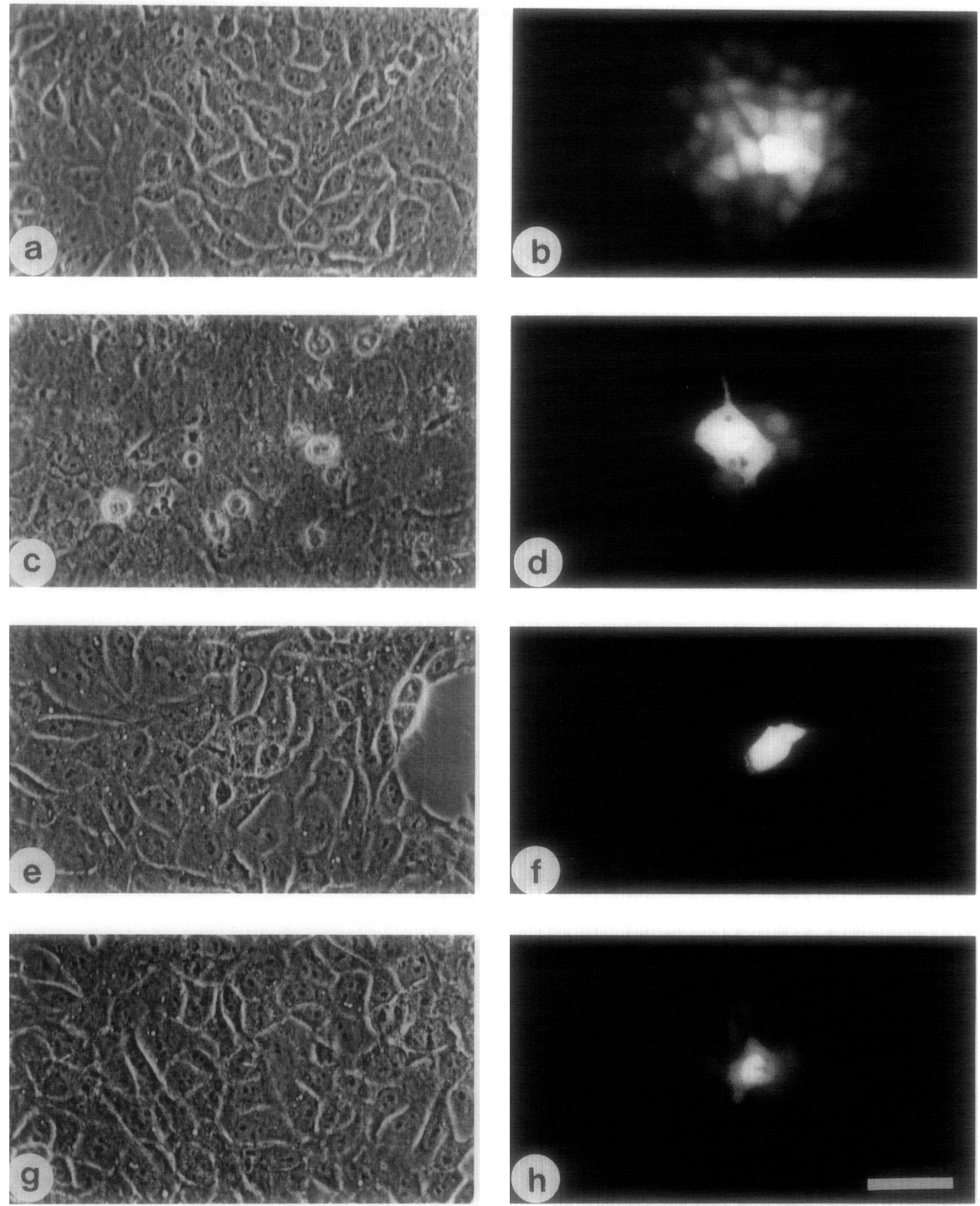

FIG. 1. The effect of $100 \mu \mathrm{mol} /$ liter RA on junctional transfer of Lucifer yellow between BRL cells in a confluent monolayer. The phase contrast and corresponding fluorescence pictures show dye transfer in control cultures $(a, b)$ and inhibition of dye transfer 30 min (c, d) and 24 $h(e, f)$ after the addition of RA. The inhibitory effect of a $30-$ min incubation was reversed $30 \mathrm{~min}$ after removal of RA ( $\mathrm{g}$, $\mathrm{h}$ ). Bar: $50 \mu \mathrm{m}$.

within $1 \mathrm{~h}$ [14]. Lucifer yellow has a molecular weight of $M_{\mathrm{r}}=\mathbf{4 5 7}$ and is, therefore, used as an indicator of intercellular transfer of metabolites. Direct evidence for met- abolic cooperation is demonstrated with an exchange of radioactive-labeled nucleotides [32]. Using this method, Pitts et al. [8] also found a reduced junctional communi- 
TABLE 1

Dye-Coupling $\left(\mathrm{CR}_{\mathrm{f}}\right)$ and Ionic-Coupling $\left(\mathrm{CR}_{\mathrm{el}}\right)$ in Monolayers of Different Cell Lines

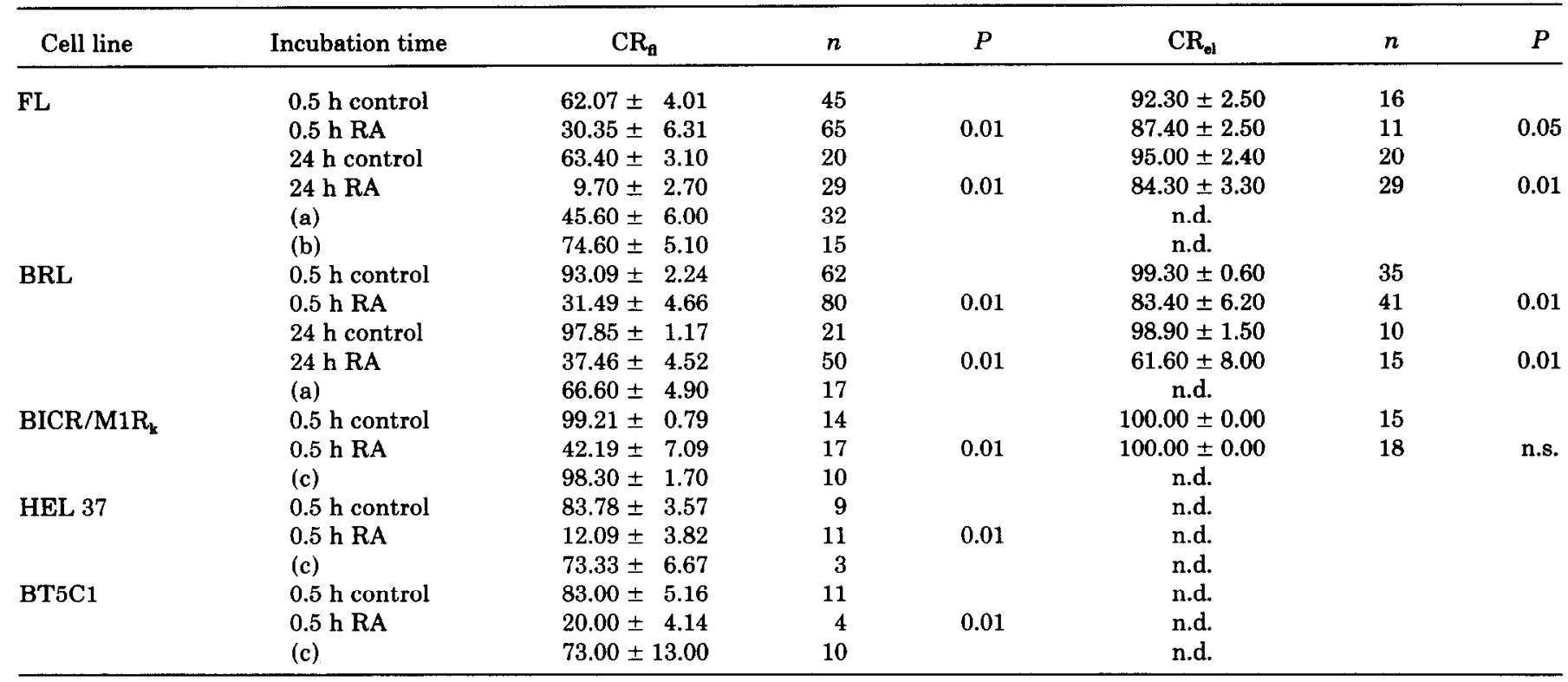

Note. Decrease of coupling after incubation with $100 \mu \mathrm{mol} /$ liter RA for $30 \mathrm{~min}$ and $24 \mathrm{~h}$. Reestablishing of coupling (a) $30 \mathrm{~min}$ or (b) $1 \mathrm{~h}$ after washing off RA with medium from cultures which had been incubated for $24 \mathrm{~h}$ with RA; (c) 30 min after washing off RA with PBS from cultures which had been incubated for $0.5 \mathrm{~h} . \mathrm{CR}_{\mathrm{fl}}$, percentage of first-order fluorescent neighbors (mean \pm standard error of the mean); $\mathrm{CR}_{\mathrm{el}}$, percentage of first-order neighbors coupled by ionic current (mean \pm standard error of the mean); $n$, number of injected cells, pooled from 1-10 dishes; n.d., not determined; $P$, statistical confidence level (Mann-Whitney $U$ test) of difference between control and RA-treated dishes; n.s., not significant $(P>0.20)$.

cation to an undetectable level after adding $100 \mu \mathrm{mol} /$ liter RA to BRL and V79 (Chinese hamster lung fibroblasts) cell cultures. They interpreted their results as an inhibitory effect by the closure of junctional channels. With the same technique, Wälder and Lützelschwab [11] found only a reduction of metabolic cooperation in

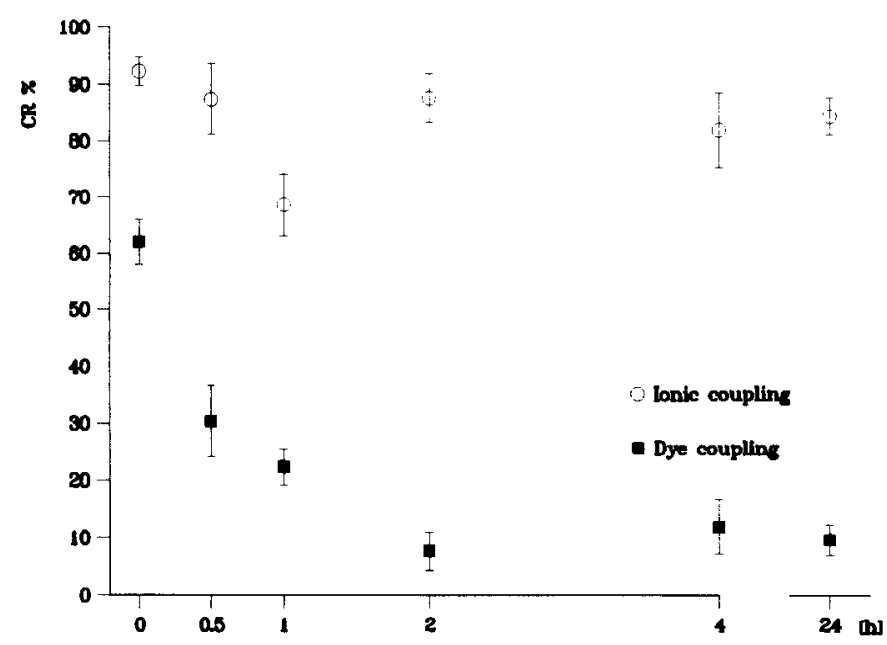

FIG. 2. Dye and current transfer in FL monolayer cells after incubation with $100 \mu \mathrm{mol} /$ liter $R A$ for different times $(O$, mean of $\mathrm{CR}_{\mathrm{el}}$; $\mathrm{E}$, mean of $\mathrm{CR}_{\mathrm{f}}$; bars: standard error of the mean). rat liver cells (RLB) at $100 \mu \mathrm{mol} /$ liter RA, an effect which the authors discussed as a persistence of a considerable portion of gap junctions in the open state.

For Lucifer yellow even an undetectable transfer of dye does not indicate a total closure of gap junction channels as we have demonstrated for different cell lines after incubation in $100 \mu \mathrm{mol} / \mathrm{liter} \mathrm{RA}$ by simultaneous measurements of dye spreading and ionic coupling. Such a discriminating intercellular communication has been observed during embryonic development,

TABLE 2

Measurements of Ionic Coupling between Cell Pairs after Incubation with RA (100 $\mu \mathrm{mol} /$ liter $)$ for $30 \mathrm{~min}$

\begin{tabular}{llccc}
\hline Cell line & Incubation & Coupling ratio $\mathrm{V}_{2} / \mathrm{V}_{1}$ & $n$ & $P$ \\
\hline \multirow{2}{*}{ FL } & control & $0.67 \pm 0.037$ & 37 & \\
& DMSO & $0.69 \pm 0.053$ & 21 & n.s. \\
& RA & $0.57 \pm 0.045$ & 35 & 0.05 \\
BRL & control & $0.61 \pm 0.047$ & 24 & \\
& DMSO & $0.58 \pm 0.054$ & 17 & n.s. \\
& RA & $0.53 \pm 0.056$ & 12 & 0.10 \\
\hline
\end{tabular}

Note. $\mathrm{V}_{2} / \mathrm{V}_{1}$, coupling ratio, mean \pm standard error of the mean; $n$, number of measurements, pooled from 2-10 dishes; $P$, statistical confidence level (Mann-Whitney $U$ test) of difference between control and RA-treated dishes; n.s., not significant $(P>0.20)$. 


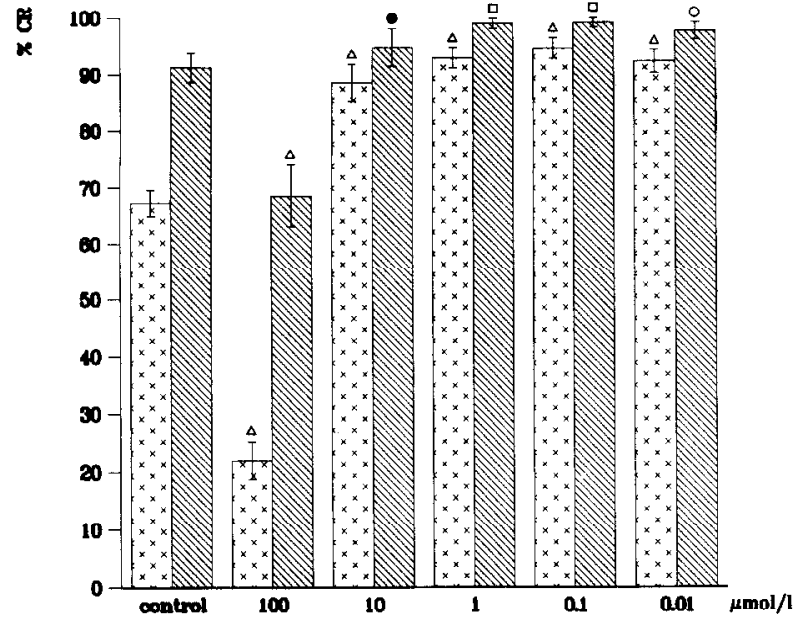

FIG. 3. Dye and current transfer in FL monolayer cells after incubation with different concentrations of RA for $1 \mathrm{~h}$ ( $\mathrm{a}$, coupling ratio of dye coupled cells; $\mathbb{}$, coupling ratio of ionically coupled cells; bars: standard error of the mean). ( $\triangle, P \leqslant 0.01 ; \square, P \leqslant 0.10 ; O, P$ $\leqslant 0.20 ; \bullet$, n.s.).

where the incidence for the transfer of molecules through gap junctions varies considerably between embryos of different species even when they are electrically coupled [33, 34]. Whether RA regulates the junctional coupling in these cases is unclear, even when it has been demonstrated that RA acts as a natural morphogenic signal in the developing chick limb bud [18]. Interestingly, low doses of RA in the nanomolar range can be sufficient for an induction of cellular differentiation [19, 35 ] and have been found to influence the intercellular dye spreading in normal and transformed cells in culture [13].

Our experiments confirm the stimulation of dye spreading for low doses of RA. In vitro, stimulation of intercellular communication can only be demonstrated with a cell line which normally does not exhibit a coupling ratio $\mathrm{CR}_{\mathrm{f}}$ of $100 \%$. The human amniotic cell line FL is electrically coupled to $C R_{\text {el }} \sim 92 \%$ whereas the dye coupling $\mathrm{CR}_{\mathrm{f}} \sim 62 \%$ (see Table 1 ). When these cells had been exposed to $100 \mu \mathrm{mol} /$ liter RA for $24 \mathrm{~h}$ they regained their original coupling ratio $\left(\mathrm{CR}_{\mathrm{f}}\right)$ within less than $1 \mathrm{~h}$ after washing off the morphogen. The coupling ratio $\left(\mathrm{CR}_{\mathrm{f}}\right)$ even exceeded the control level (see Table 1 ), which we interpreted as an incomplete washing and, therefore, tested the influence of lower doses (Fig. 3). Every dose smaller than $10 \mu \mathrm{mol} /$ liter RA significantly $(P \leqslant 0.01)$ increased the dye coupling ratio $\left(\mathrm{CR}_{\mathrm{f}}\right)$ to about $90 \%$ and the electrical coupling ratio $\left(\mathrm{CR}_{\mathrm{el}}\right)$ reached almost $100 \%(P \leqslant 0.10 ; P \leqslant 0.20)$.

Stillwell et al. [36] showed a decrease of the electrical resistance of RA-containing artifical lipid bilayers, an effect which should be mediated by intercalation of RA into the lipid bilayer. Applied to living cells, RA may cause steric irregularities in the cell membrane and thus induce a partial closure of membrane channels. Our preliminary data indicate that not only gap junction channels but also other membrane channels are affected. The input resistance of FL cell pairs increased from $\sim 1$ G $\Omega$ to $\sim 2$ G $\Omega$ when the cells were incubated with 100 $\mu \mathrm{mol} / \mathrm{liter}$ RA. As can be seen from Fig. 2 the same concentration of RA reduced the junctional permeability in a graded process, an effect which can also be interpreted by steric irregularities. Furthermore, it explains why the input resistance of a plasma membrane is increased without noticeable changes of the gap junction plaque sizes: the freeze fracture technique cannot distinguish between open and closed gap junction channels. Whether a specific interaction of RA with cellular receptors $[37,38]$ may be responsible for the observed stimulation of gap junctional permeability when lower doses of RA were applied remains unresolved. Preliminary results [39] indicate that at the single channel level the conductance of gap junction channels in human hepatoma cells (PLC) remains unaffected under $10 \mu \mathrm{mol} /$ liter RA. Stimulation and reduction of gap junctional permeability may interfere with different regulatory sites. Each, however, may alter the gap junction channel kinetics.

We thank Ms. S. Becker, U. Reber, B. Rehkopf, and S. Rhein for technical assistance and Mr. R. Eckert for helpful discussions. This work was supported by the Deutsche Forschungsgemeinschaft (Hu 204/9-4).

\section{REFERENCES}

1. MacDonald, C. (1985) Essays Biochem. 21, 86-118.

2. Flagg-Newton, J. L., Simpson, I., and Loewenstein, W. R. (1979) Science 205, 404-407.

3. DeMello, W. C. (1982) Prog. Biophys. Mol. Biol. 39, 147-182.

4. Daniel, E. E. (1987) in Cell-to-Cell Communication (DeMello, W. C., Ed.), pp. 149-185. Plenum Press, New York.

5. Jaslove, S. W., and Brink, P. R. (1987) in Cell-to-Cell Communication (DeMello, W. C., Ed.), pp. 102-147. Plenum Press, New York.

6. Loewenstein, W. R. (1979) Biochim. Biophys. Acta 560, 1-65.

7. Finbow, M. E. (1982) in Functional Integration of Cells in Animal Tissues. British Society for Cell Biology, Symposium 5. (Pitts, J. D., and Finbow, M. E., Eds.), pp. 1-37. Cambridge Univ. Press, London.

8. Pitts, J. D., and Finbow, M. E. (1986) J. Cell Sci. 4, 239-266.

9. Pitts, J. D., Bürk, R. R., and Murphy, J. P. (1981) Cell Biol. Intl. Rep. 5 (suppl. A), 45.

10. Pitts, J. D., Hamilton, A. E., Kam, E., Burk, R. R., and Murphy, J. P. (1986) Carcinogenesis 7, 1003-1010.

11. Wälder, L., and Lützelschwab, R. (1984) Exp. Cell Res. 152, 66-76.

12. Mehta, P. P., Bertram, J. S., and Loewenstein, W. R. (1986) Cell 44, 187-196.

13. Mehta, P. P., Bertram, J. S., and Loewenstein, W. R. (1989) J. Cell Biol. 108, 1053-1065.

14. Welsch, F. (1987) in Biochemical Mechanism and Regulation of Intercellular Communication (Milman, H., and Elmore, E., Eds.), Vol. 14, pp. 113-136, Princeton Scientific Publishing Co., Inc., Princeton, NJ. 
15. Wolbach, S. B., and Howe, P. R. (1925) J. Exp. Med. 42, 753777.

16. Lotan, R. (1980) Biochim. Biophys. Acta 605, 33-91.

17. Sporn, M. B., and Roberts, A. B. (1983) Cancer Res. 43, 30343040.

18. Thaller, Ch., and Eichele, G. (1987) Nature 327, 625-628.

19. Gabbert, H. E., Gerharz, C.-D., Ramp, U., Hoffmann, J., Oster, O., Oesch, F., and Doehmer, J. (1990) Int. J. Cancer 45, 724-730.

20. Brümmer, F., Bühle, P., and Hülser, D. F. (1988) Eur. J. Cell Biol. 46(Suppl. 22), 12.

21. Bühle, P., Stein, J.-C., Zempel, G., Brümmer, F., Gabbert, H. E., and Hülser, D. F. (1989) Eur. J. Cell Biol. 48(Suppl. 26), 9.

22. Rajewsky, M. F., and Grüneisen, A. (1972) Eur. J. Immunol. 2, 445-447.

23. Laerum, O. D., and Rajewsky, M. F. (1975) J. Natl. Cancer Inst. 55, 1177-1187.

24. Coon, H. G. (1968) J. Cell Biol. 39, 29a.

25. Fogh, J., and Lund, R. O. (1957) Proc. Soc. Exp. Biol. Med. 94, 532-537.

26. Murray, A. W., and Fitzgerald, D. J. (1979) Biochem. Biophys. Res. Commun. 91, 395-401.

27. Flagg-Newton, J. L., and Loewenstein, W. R. (1981) J. Membr. Biol. 63, 123-131.
28. Dertinger, H., and Hülser, D. F. (1984) in Recent Results in Cancer (Acker, H., Carlsson, I., Durand, R., and Sutherland, R. M., Eds.), Vol. 95, pp. 67-83. Springer-Verlag, Berlin/Heidelberg.

29. Loewenstein, W. R., and Kanno, Y. (1964) J. Cell Biol. 22, 565586.

30. Lienert, G. A. (1973) Verteilungsfreie Methoden in der Biostatistik. Band I. Verlag A. Hain, Meisenheim am Glan.

31. Lorenz, R. J. (1984) Grundbegriffe der Biometrie. G. Fischer Verlag, Stuttgart.

32. Subak-Sharpe, H., Bürk, R. R., and Pitts, J. D. (1969) J. Cell Sci. 4, 353-367.

33. Lo, C. W., and Gilula, N. B. (1979) Cell 18, 411-422.

34. Guthrie, S., Turin, L., and Warner, A. (1988) Development 103 , 769-783.

35. Slack, J. M. W. (1987) Nature 327, 553-554.

36. Stillwell, W., Ricketts, M., Hudson, H., and Nahmias, S. (1982) Biochim. Biophys. Acta 688, 653-659.

37. Petkovich, M., Brand, N. J., Krust, A., and Chambon, P. (1987) Nature 330, 444-450.

38. Ong, D. E., and Chytil, F. (1988) Arch. Biochem. Biophys. 267, 474-478.

39. Paschke, D. (1989) Dissertation, Biologisches Institut der Universität Stuttgart.

Received January 28, 1991

Revised version received May 16, 1991 